\title{
Metody ilościowej analizy szumu napięciowego Barkhausena
}

\author{
Barkhausen noise quantitative analysis methods
}

\section{Streszczenie}

Przeprowadzone badania doświadczalne z wykorzystaniem magnetycznego szumu Barkhausena (MBN) wykazały jego silne powiązanie z mikrostrukturą i stanem naprężenia w materiałach o właściwościach ferromagnetycznych. Materiały te są szeroko stosowanych w przemyśle, co jest argumentem uzasadniającym prowadzenie prac badawczo-rozwojowych związanych z tym zjawiskiem. W artykule uwaga skupia się na metodach analizy ilościowej MBN, czyli sposobach otrzymywania informacji diagnostycznej. Wymienione i opisane zostały zarówno popularne metody punktowe jak i te wykorzystujące właściwości czasowo-częstotliwosciowe sygnałów niestacjonarnych.

Słowa kluczowe: szum Barkhausena; analiza czasowo-częstotliwościowa; rozkład wysokości impulsów; STFT

\begin{abstract}
The results of experimental studies of application of magnetic Barkhausen noise (MBN) showed his strong relationship with the microstructure and stress state of the ferromagnetic material. These materials are widely used in the industry, what is the argument to conduct more detailed research assosiated with this phenomenon. In paper attention is paid to quantitative MBN analysis method, that means the way for obtaining diagnostic information. Popular scalar method and as well joint time-frequency method was mentioned and described.
\end{abstract}

Keywords: Barkhausen noise; joint time-frequency analysis; pulse height distribution; STFT

\section{Wstęp}

Rozwój diagnostyki opartej na szumie Barkhausena zależy od wykorzystania synergicznej wiedzy z różnych obszarów takich jak nauka o materiałach, elektronika, mechanika i analizy sygnału. Sposób pozyskania informacji z sygnału szumu Barkhausena, będzie wpływał na stopień jakości i niezawodności procesu diagnostyki. Powszechnie używa się najczęściej do tego celu parametrów skalarnych (punktowych) m.in. maksymalnej amplitudy impulsów napięciowych czy wartości skutecznej sygnału. W literaturze zajmowano się również wyznaczaniem rozkładu wysokości impulsów oraz analizowano widmo częstotliwościowe sygnału. Badania doświadczalne autorów wykazały, że w przypadku odkształceń plastycznych, analiza MBN w dziedzinie czasu okazuje się niewystarczająca. Jest to spowodowane nieliniowością właściwości magnetycznych materiału, które mogą powodować, że analizowane wielkości charakterystyczne przyjmują zbliżone wartości dla zupełnie skrajnych stanów tworzywa $[1,25,26]$. Z racji niestacjonarności sygnału MBN, co znaczy, że jego cechy statystyczne i widmo częstotliwości ulegają zmianom w czasie [2], można posłużyć się reprezentacjami czasowo-częstotliwościowymi sygnału (ang. JTFA-Joint Time-Frequency
Analysis). Dalsza część artykułu koncentruje się na krótkim wyjaśnieniu czym jest szum Barkhausena, krótkim wstępem do teorii analizy sygnałów oraz części opisu i analizy poszczególnych wielkości i metod używanych do tej pory i tych, które posiadają duże możliwości rozwoju w przyszłości.

\section{Szum Barkhausena}

Gdy materiał ferromagnetyczny zostanie umieszczony w cewce, do której podłączymy oscyloskop, to pod wpływem magnesowania materiału zmiennym zewnętrznym polem magnetycznym, będziemy obserwować na ekranie oscyloskopu szereg impulsów napięciowych, zwanych szumem Barkhausena. Efekt ten powstaje wskutek nagłego wytwarzania sił elektromotorycznych indukowanych przez gwałtowne skoki magnetyzacji materiału [3]. Przyczyna tej nieciągłości w zmianie magnetyzacji, w sposób wystarczający tłumaczona jest domenową teorią ferromagnetyków, która zostata potwierdzona eksperymentalnie [4]. Zgodnie z nią ferromagnetyki zbudowane są z małych obszarów

mgr inż. Krzysztof Fryczowski; dr hab. inż. Maciej Roskosz - Politechnika Śląska, Instytut Maszyn i Urządzeń Energetycznych. Autor korespondencyjny/Corresponding author: krzysztof.fryczowski@polsl.pl 
(rzędu kilku do kilkunastu mikrometrów) zwanych domenami magnetycznymi. W każdej domenie namagnesowanie osiąga stan nasycenia. W stanie nienamagnesowanym obserwuje się chaotyczne ułożenie domen, wynikające $z$ dążenia do osiągnięcia minimum całkowitej energii magnetycznej. Sąsiednie dwie domeny magnetyczne o przeciwnym kierunkach wektora magnetyzacji oddzielone są od siebie tzw.ścianą domenową. Skoki magnetyzacji są wynikiem nagłych zmian usytuowania ścian między przyległymi domenami [3]. Źródło zmiennego pola magnetycznego $\mathrm{w}$ pobliżu powierzchni próbki powoduje początkowo odwracalne, a następnie nieodwracalne przemieszczenia ścian domenowych, powodując rozrost objętości domen magnetycznych, których wektor magnetyzacji jest najbardziej zgodny z wektorem zewnętrznego pola magnetycznego kosztem objętości domen nieuprzywilejowanych, a przy dużych natężeniach pola magnetycznego nagłych obrotów wektora magnetyzacji domeny. Niejednorodności struktury krystalograficznej ferromagnetyków, czyli defekty sieci krystalicznej, wtrącenia niemetaliczne, zanieczyszczenia pustki, niejednorodność składu chemicznego, dyslokacje, granice ziarn stanowią blokady w ruchu ścian międzydomenowych, które również przyczyniają się do skokowych zmian magnetyzacji, gdyż aby ruch domeny mógł nastąpić musi nastąpić wzrost energii ściany realizowany przez wzrost natężenia zewnętrznego pola magnetycznego. Jako że ruch domen magnetycznych jest uzależniony od lokalnych właściwości materiału, uważa się, że za pomocą efektu Barkhausena można określić zarówno stan mikrostruktury jak i stan naprężenia w materiale [5].

\section{Metody analizy ilościowej sygnału szumu napięciowego Barkhausena}

Celem każdej analizy sygnału jest otrzymanie użytecznej informacji. W przypadku pomiaru szumu Barkhausena mierzony jest szybkozmienny sygnał napięciowy, który może być rozpatrywany jako funkcja zmiennawczasie,codajemożliwośćzastosowanianarzędzi analizy matematycznej. Sygnał ten jest nośnikiem informacji na temat zachowania się domen magnetycznych badanego ferromagnetyka, które bezpośrednio są związane zarówno ze stanem mikrostruktury materiału jak i stanem naprężenia. W celu ekstrakcji informacji sygnał poddaje się różnego rodzaju przetworzeniom. Metody cyfrowego przetwarzania sygnałów, wykonywane są na sygnałach dyskretnych, które powstają w wyniku spróbkowania i skwantowania sygnału analogowego realizowanego przez przetworniki analagowo-cyfrowe. Ważnym parametrem w przypadku akwizycji sygnału jest częstotliwość próbkowania fpr. Sygnał napięciowy szumu Barkhausena indukowany w cewce jest bardzo złożony - ma charakter niestacjonarnego szumu w zakresie częstotliwości od 0,1 do $300 \mathrm{kHz}$ i amplitudzie rzędu $\mathrm{mV}$ na zwój dla średnicy cewek rzędu $10 \mathrm{~mm}$ [6]. Zgodnie z twierdzeniem o próbkowaniu Kotielnikova-Shannona częstotliwość próbkowania powinna być co najmniej dwa razy większa od maksymalnej częstotliwości występującej w sygnale [2] co w naszym przypadku przekłada się na minimalną częstotliwość próbkowania równą $600 \mathrm{kHz}$.

Wśród dostępnych metod analizy sygnałów wyróżnia się analizy przebiegów czasowych, korelacyjne, statystyczne, częstotliwościowe, oraz czasowo-częstotliwościowe.

\section{Analiza MBN w dziedzinie czasu}

Dziedzina czasu jest dziedziną w której obserwujemy i rejestrujemy sygnał szumowy Barkhausena. Do podstawowych cech statystycznych tego sygnału zaliczamy: wartość skuteczną sygnału URMS, energię sygnału EBN oraz wielkości charakterystyczne związane z obwiednią sygnału. Do tej dziedziny zaliczono również tzw. rozkład liczby zdarzeń. W celu zmniejszenia niepewności powinny one być uśrednieniem z kilku zrealizowanych cyklów przemagnesowania.

\section{Wartość skuteczna MBN}

Ze względu na to, że zmierzony sygnał szumu Barkhausena charakteryzuje się występowaniem zarówno dodatnich jak i ujemnych impulsów napięcia $U_{B N}$ (por. rys. 1), do jego charakteryzowania najczęściej stosowana jest wartość skuteczna (ang. Root Mean Square) wielokrotnie wymieniana w literaturze $[7 \div 9]$. Oblicza się ją dla próbek sygnału, które spełniają określone kryteria (np. próbki o napięciu większym od pewnej wartości) i można ją wyrazić jako:

$$
\mathrm{U}_{\mathrm{RMS}}=\sqrt{\frac{1}{\mathrm{~N}} \sum_{\mathrm{i}=1}^{\mathrm{N}}\left(\mathrm{U}_{\mathrm{BNi}}\right)^{2}}
$$

gdzie:

$\mathrm{N}$ - liczba próbek sygnału, z których obliczana jest średnia kwadratowa,

$\mathrm{U}_{\mathrm{BNi}}$ - wartość napięcia zarejestrowanego w cewce pomiarowej dla i-tej próbki sygnału.

\section{Energia MBN}

Innym dosyć często stosowanym parametrem jest energia MBN EBN $[9,10]$, którą można wyrazić w następujący sposób:

$$
\mathrm{E}_{\mathrm{BN}}=\sum_{\mathrm{i}=1}^{\mathrm{N}}\left[\left(\mathrm{U}_{\mathrm{BNi}}\right)^{2} \Delta \mathrm{t}\right] \Delta \mathrm{t}=1 / \mathrm{f}_{\mathrm{pr}}
$$

gdzie:

$\mathrm{f}_{\mathrm{pr}}$ - częstotliwość próbkowania sygnału.

\section{Obwiednia przebiegu czasowego MBN}

Aby otrzymać obwiednię szumu Barkhausena, trzeba wykonać na próbkach sygnału operację uśredniania wygładzającego. Celem tego rodzaju uśredniania jest usunięcie krótkotrwałych wysokoczęstotliwościowych fluktuacji występujących w sygnale [11].

Istnieje kilka metod wygładzania sygnału ale najczęściej wykorzystuje się metodę średniej ruchomej. Metoda ta polega na obliczeniu wartości skutecznej sygnału dla szerokości okna czasowego obserwacji k. Okno to następnie jest przesuwane o wybraną liczbę próbek sygnału a operacja uśredniania jest powtarzana dla nowego zestawu próbek. Autorzy proponują wprowadzenie pojęcia ruchomej centralnej średniej kwadratowej CQMA (ang. Central Quadratic Moving Average), w której wartość średnia przypisywana jest dla czasu będącego medianą zakresu objętego oknem czasowym.

$\operatorname{CQMA}[\mathrm{i}]=\sqrt{\frac{1}{\mathrm{k}} \sum_{\mathrm{i}}^{\mathrm{i}+\mathrm{k}}\left(\mathrm{U}_{\mathrm{BNi}}\right)^{2}}, \quad \mathrm{i} \in(1, \mathrm{~N}-\mathrm{k})$ 
gdzie:

i - numer próbki początku okna czasowego,

N - całkowita liczba próbek,

k - szerokość okna czasowego obserwacji.

Zadaniem wymagającym sporo uwagi jest dobór szerokości okna wygładzania, ponieważ zbyt wąskie okno spowoduje niewielkie wygładzenie danych, natomiast zbyt szerokie okno może doprowadzić do dużej utraty informacji.

Oprócz metody średniej ruchomej można wykorzystać operację filtrowania sygnału (np. filtru Savitzkiego-Golaya) oraz metodę wygładzania za pomocą funkcji sklejanych.

W wyniku operacji wygładzania otrzymuje się tzw. obwiednię przebiegu czasowego szumu Barkhausena. Na obwiedni można wyznaczyć punkty i obszary charakterystyczne (por. rys. 2):

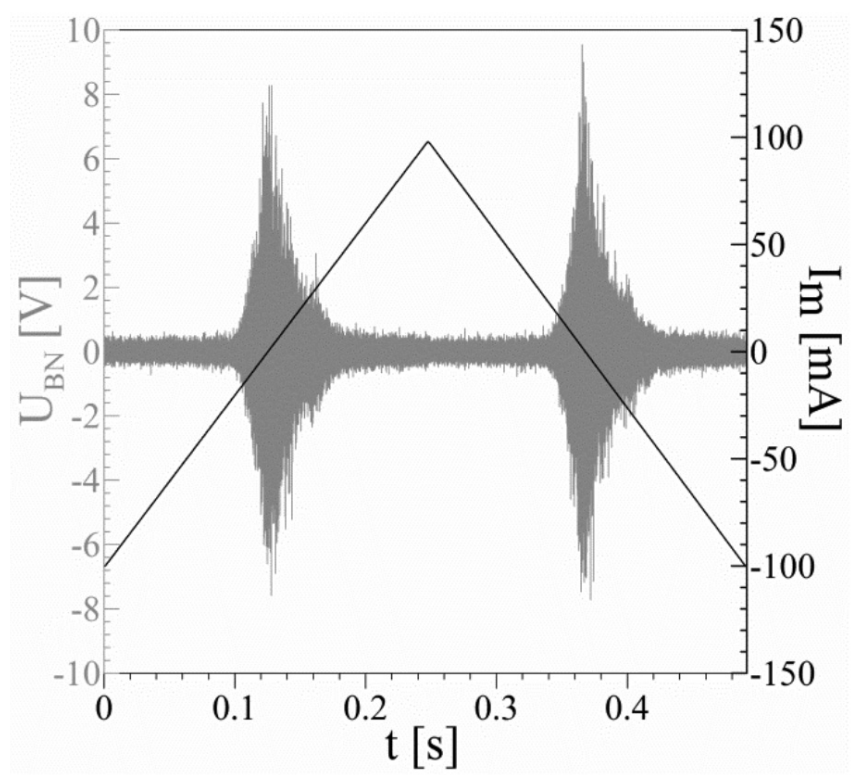

Rys. 1. Przykładowy sygnał szumu Barkhausena Fig. 1. Example of Barkhausen noise signal

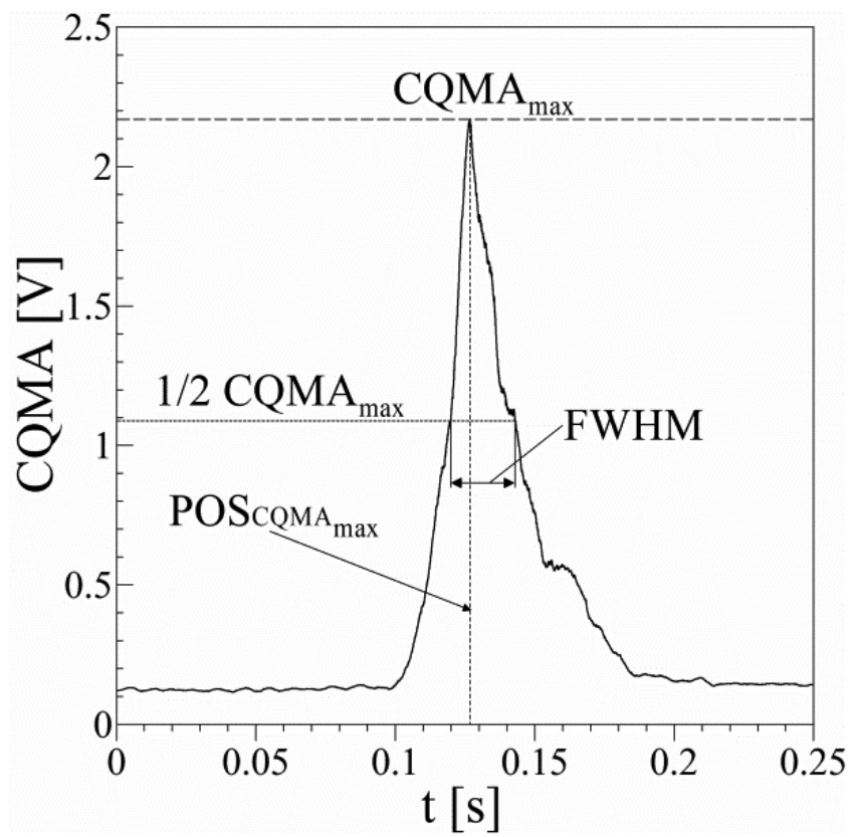

Rys. 2. Obwiednia przebiegu czasowego szumu Barkhausena zarejestrowanego dla połówki cyklu przemagnesowania ze wskazaniem charakterystycznych wielkości

Fig. 2. Envelope of Barkhausen noise signal, for half magnetization cycle
- wartość maksymalna obwiedni CQMA max $_{\text {(zastosowana }}$ m.in. w $[10 \div 13])$

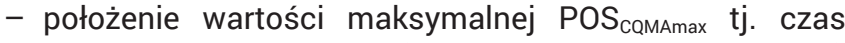
bądź wartość napięcia (ewentualnie natężenia prądu) w obwodzie magnesującym w którym wystąpiła maksymalna wartość obwiedni (zastosowana m.in. w [12,14])

- szerokość obwiedni dla 1/2 CQMA max $_{\text {(ang. FWHM-Full }}$ Width Half Maximum) (zastosowana m.in. w [12,15]).

\section{Rozkład liczby zdarzeń (ang. Pulse Height Distribution}

Zmierzony sygnał szumu Barkhausena stanowi zbiór impulsów napięciowych, wśród których możemy wyróżnić tzw. zdarzenia. Dla ustalonego progu napięciowego, wystąpienie zdarzenia określane jest na podstawie 3 kolejnych próbek sygnału których wartości są wyższe od tego progu i w którym próbka środkowa ma wartość wyższą od próbek skrajnych. Wyniki takiej analizy przedstawiono na rysunkach 3 i 4, przy czym rysunek 3 przedstawia rozkład całkowitej liczby zdarzeń powyżej zadanego progu napięciowego $U_{g}$, natomiast rysunek 4 prezentuje międzyprogową liczbę zdarzeń, tj. różnicę liczby zdarzeń pomiędzy dwoma kolejnymi progami.

Zastanowienia wymaga dobór zakresu wartości napięcia progowego, z którego będą brane wartości liczby zliczeń w celu zapewnienia wiarygodności analizy, ze względu na obecność zakłóceń pochodzących z otoczenia charakteryzujących się niewielkimi wartościami napięcia.

Przykładowe zastosowanie rozkładu liczby zdarzen można znaleźć w [16, 17].

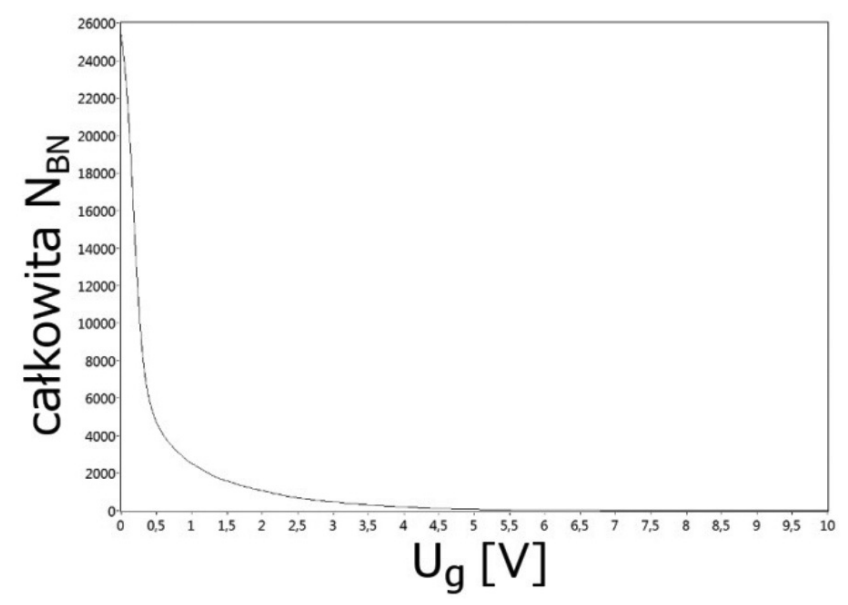

Rys. 3. Rozkład całkowitej liczby zdarzeń powyżej zadanego progu napięciowego

Fig. 3. Pulse Height Distribution - total number of events above the threshold voltage

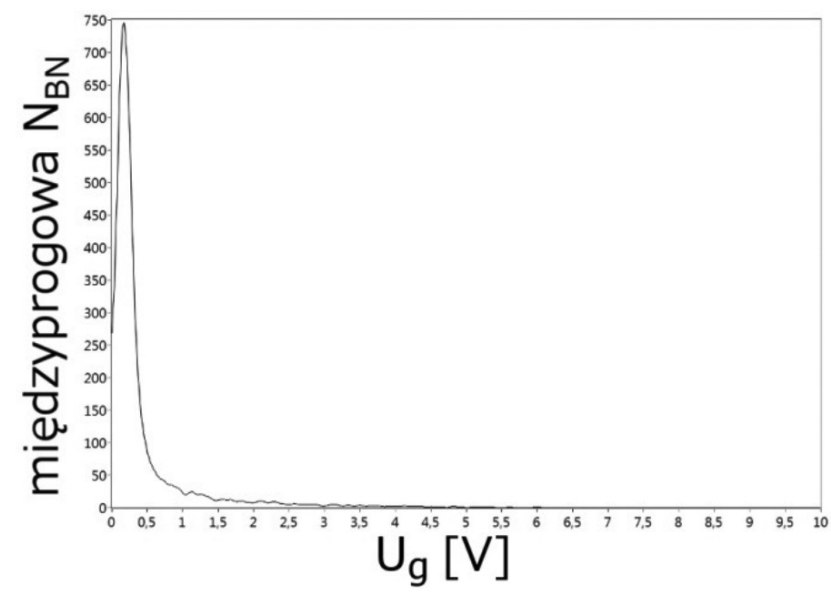

Rys. 4. Rozkład międzyprogowej liczby zdarzeń

Fig. 4. Pulse Height Distribution - interval number of events 


\section{Analiza częstotliwościowa MBN}

W analizie częstotliwościowej sygnału następuje transformacja dziedziny opisu sygnału z czasowej na częstotliwościową. Jej celem jest uzyskanie zbioru cech sygnału, które nie są widoczne w przypadku dziedziny czasu. Przejście z jednej dziedziny do drugiej nie wiąże się z utratą informacji, a jedynie jest odmiennym sposobem zaprezentowania cech badanego sygnału [11].

Zadaniem analizy częstotliwościowej jest badanie parametrów i właściwości sygnału poprzez analizę jego struktury częstotliwościowej, umożliwioną dzięki zastosowaniu transformacji Fouriera [2] w wyniku której otrzymujemy tzw. widmo częstotliwościowe sygnału, prezentujące miarę korelacji (podobieństwa) sygnału analizowanego do poszczególnych zespolonych funkcji harmonicznych. Widmo częstotliwościowe sygnału z rysunku 1 przedstawiono na rysunku 5. Ze względu na dużą nieregularność prążków widma, aby dalsza analiza była możliwa, wymaga wygładzenia rozkładu i jego wynik przedstawiono na rysunku 6. Dla tak przygotowanego widma jesteśmy w stanie np. analizować wysokość amplitudy dla poszczególnych składowych częstotliwości.

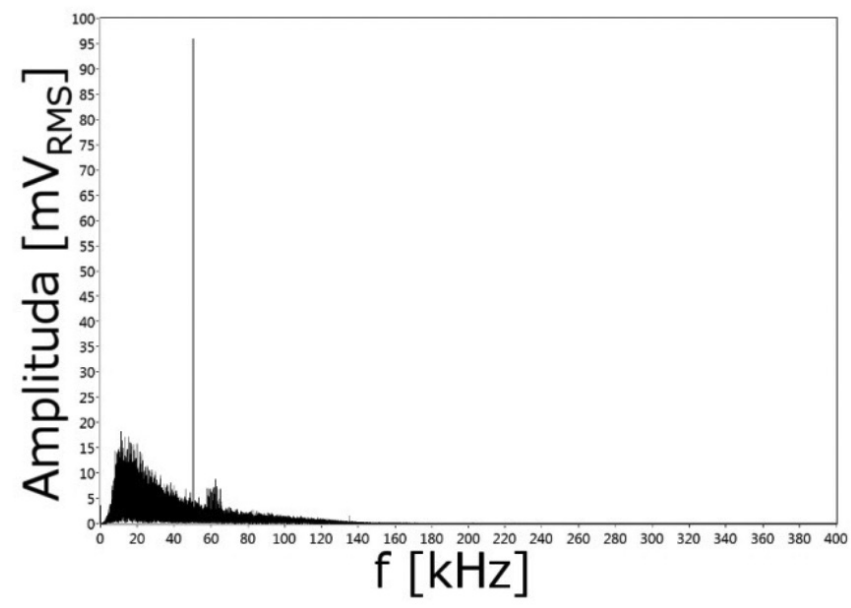

Rys. 5. Widmo częstotliwościowe Fouriera sygnału z rysunek 1 Fig. 5. Pulse Height Distribution - total number of events above the threshold voltage

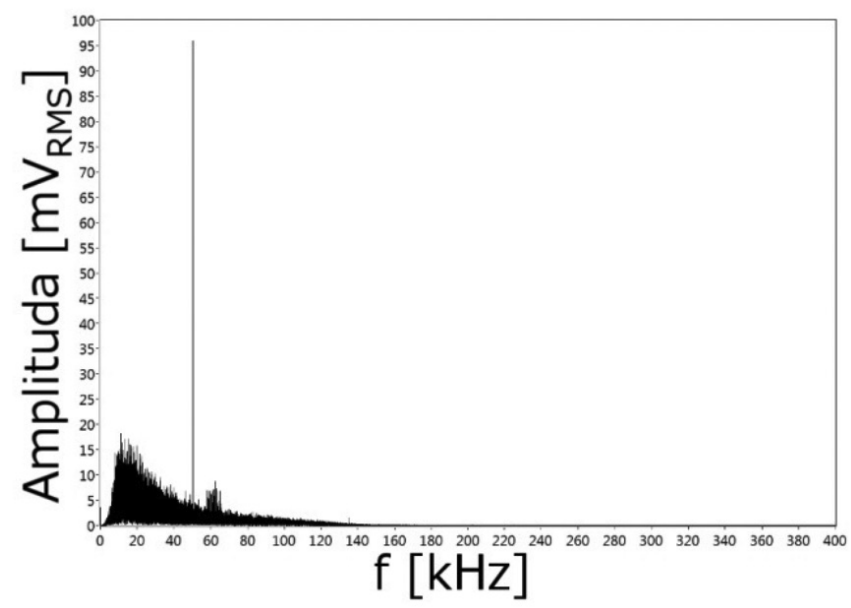

Rys. 6. Uśrednione widmo częstotliwościowe z rysunek 5 Fig. 6. Average frequency spectrum from Figure 5

Można zauważyć, że widmo sygnału z rysunku 1 ogranicza się do częstotliwości ok. $200 \mathrm{kHz}$ - do tego miejsca zauważalne są niezerowe amplitudy składowych harmonicznych sygnału.

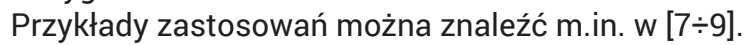

\section{Analiza czasowo-częstotliwościowa MBN}

Jak już wspomniano MBN jest sygnałem niestacjonarnym - transformacja Fouriera w tym przypadku okazuje się niewystarczającym źródłem informacji, ponieważ daje tylko uśrednione wyniki w całym przedziale czasu. Z tego względu coraz większą popularność zyskują metody analizy czasowo-częstotliwościowej - pozwalające na obserwację zmian składowych częstotliwości sygnału w funkcji czasu.

Można wyróżnić następujące reprezentacje czasowoczęstotliwościowe sygnału:

- krótkoczasową transformację Fouriera (STFT - Short Time Fourier Transform).

- transformację Gabora,

- transformację Wignera-Ville'a,

- rodzinę transformacji należących do tzw. klasy Cohena,

- transformację falkową.

\section{Krótkoczasowa transformacja Fouriera STFT}

STFT opiera się na podziału sygnału na krótkie fragmenty sygnału, które mogą być uznawane za stacjonarne. Transformacja odbywa się w dwóch krokach: pierwszy polega na podziale sygnału na jego stacjonarne podrealizacje po czym dla każdej z nich wyznaczane jest widmo częstotliwościowe. Można to wyrazić za pomocą wyrażenia [11]:

$$
S(t, f)=\int_{-\infty}^{+\infty} x(t) w(\tau-t) e^{-j f t} d \tau
$$

gdzie:

$\mathrm{x}(\mathrm{t})$ - analizowany sygnał,

$\mathrm{w}(\mathrm{T}-\mathrm{t})$ - funkcja okna czasowego,

$\mathrm{t}$ - parametr przesunięcia okna czasowego,

$\mathrm{e}^{-\mathrm{jft}} \quad$ - funkcja harmoniczna w postaci zespolonej.

Ograniczeniem jest tutaj, że funkcją bazową może być tylko funkcja harmoniczna $e^{-j f t}$.

Przykłady zastosowań można znaleźć m.in. w [18,19].

\section{Transformacja Gabora}

Transformacja Gabora może traktowana jako specyficzny przypadek STFT. Analizowany sygnał jest przedstawiany jako suma funkcji bazowych, które powstają z funkcji prototypowej, którą najczęściej jest okno gaussowskie, w wyniku jej przesuwania w osi czasu i częstotliwości (wymnożenie z zespolonymi funkcjami harmonicznymi) [2]. Dzięki zmianie parametru okna gaussowskiego, możliwe jest dostosowanie rozdzielczości w dziedzinie czasu. Wynikowa czasowo-częstotliwościowa reprezentacja Gabora ciągłego sygnału x(t) jest definiowana jako [2]:

$$
S_{x}(m, n)=\left|c_{m, n}\right|^{2}
$$

gdzie:

$\mathrm{c}_{\mathrm{m}, \mathrm{n}}-$ współczynniki dekompozycji;

$m$ - przesunięcie $w$ dziedzinie czas,

n - przesunięcie w dziedzinie częstotliwości.

Przykłady zastosowań można znaleźć m.in. w [20].

\section{Transformacja Wignera-Ville'a}

Jej cecha charakterystyczną jest brak ograniczenia rozdzielczości, zarówno w dziedzinie czasie jak i w dzidzinie częstotliwości [11]. Transformata Wignera-Ville'a jest ogólną formą przekształcenia, w którym nie stosuje się żadnych funkcji bazowych. Przekształcenie to można zapisać w postaci następującej zależności [11]:

$$
\mathrm{W}_{\mathrm{S}}(\tau, \mathrm{f})=\int_{-\infty}^{\infty} \mathrm{x}\left(\mathrm{t}+\frac{\tau}{2}\right) \mathrm{x}^{*}\left(\mathrm{t}-\frac{\tau}{2}\right) \mathrm{e}^{-\mathrm{jft}} \mathrm{dt}
$$


gdzie:

$x(t)$ - analizowany sygnat,

$x^{\star}(t)$ - sygnał sprzężony do $x(t)$.

Jedną z wad jest pojawianie się pomiędzy dwiema składowymi częstotliwościowymi interferencji skrośnych (ang. cross-term) oraz często trudność w interpetacji jej wyników [11].

Przykłady zastosowań można znaleźć m.in. w [7,21,22].

\section{Rodzina transformacji należących do tzw. klasy Cohena}

Reprezentacje czasowo-częstotliwościowe z klasy Cohena stanowią bardzo wartościowe uogólnienie transformacji Wignera-Ville'a. Stanowią propozycje wygładzania reprezentacji Wignera-Ville'a, w wyniku czego następuje redukcja interferencji skrośnych występujących w jego widmie czasowo-częstotliwościowym. W wyniku wygładzania pogarszana jest rozdzielczość czasowo-częstotliwościowa, zyskując większą czytelność. Ogólna definicja została tutaj pominięta. W [7] zaprezentowano wyniki zastosowania wygładzonej pseudoreprezentacji Wignera-Ville'a należącej do klasy Cohena.

Przykłady zastosowań można znaleźć m.in. w [7,22].

\section{Transformacja falkowa}

Ciągła transformacja falkowa definiowana jest następująco [11]:

$$
S(a, b)=a^{-\frac{1}{2}} \int_{-\infty}^{\infty} x(t) \psi\left(\frac{t-b}{a}\right) d t
$$

gdzie:

a - skala, będąca odwrotnością częstotliwości,

b - przesunięcie w dziedzinie czasu,

$\mathrm{x}(\mathrm{t}) \quad$ - analizowany sygnał,

$\psi \quad-$ funkcja falkowa,

$\psi[(t-b) / a]-$ jądro przekształcenia falkowego,

$s(a, b) \quad$ - współczynniki falkowe.

Przykłady zastosowania analizy falkowej do analizy szumu Barkhausena można znaleźć w [21 $\div 24]$.

\section{Przykładowe wyniki analizy czasowo-częstotliwościowej}

Reprezentacje czasowo-częstotliwościowe zwykle przedstawiane są jako wykresy 3D lub wykresy konturowe. Do przeprowadzenia analiz czasowo-częstotliwościowych wykorzystano procedury pakietu narzędziowego JTFA programu LabVIEW 2016. Na rysunkach $7 \div 9$ przedstawiono wynikowe wykresy konturowe spektrogrmów wybranych metod analizy czasowo-częstotliwosciowej przeprowadzonych dla sygnału z rysunku 1. Parametry skali kolorów zostały dobrane optymalnie do wartości współczynników transformacji.

Zadaniem problematycznym w przypadku analizy czasowo-częstotliwościowej jest wybór odpowiedniej konfiguracji komórek tablicy dekompozycji oraz wybór właściwych funkcji bazowych, aby uzyskać jak najlepsze odwzorowanie cech sygnału [2]. Analizując spektrogramy z rysunków 7\%9, można stwierdzić, że wyniki transformacji Gabora zawierają największą informatywność, gdyż można bez problemy wyróżnić składowe harmoniczne sygnału w okolicach częstotliwości 50, 175, 225 i $275 \mathrm{kHz}$ co również jest widoczne w przypadku STFT lecz w tym przypadku mamy duże rozmycie widma w zakresie wysokich częstotliwości dla chwil czasowych ok. 125 i 370 ms. W wyniku transformacji Wigner-Ville'a otrzymano najgorszą reprezentację czasowo-częstotliwościową.

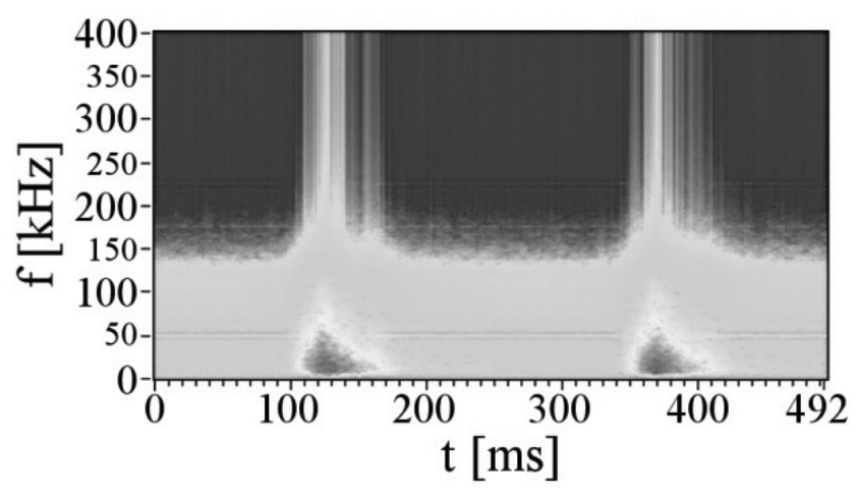

Rys. 7. Spektrogram STFT z użyciem okna prostokątnego Fig. 7. Rectangle windowed STFT spectrogram

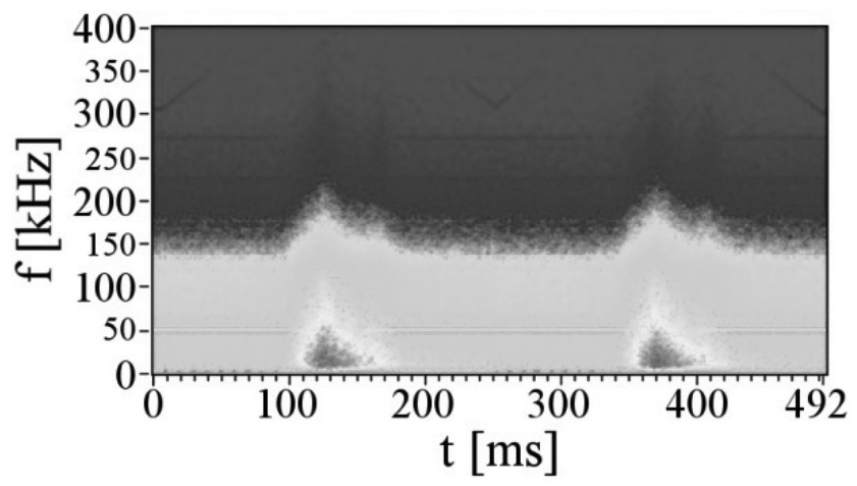

Rys. 8. Spektrogram transformacji Gabora Fig. 8. Gabor transform spectrogram

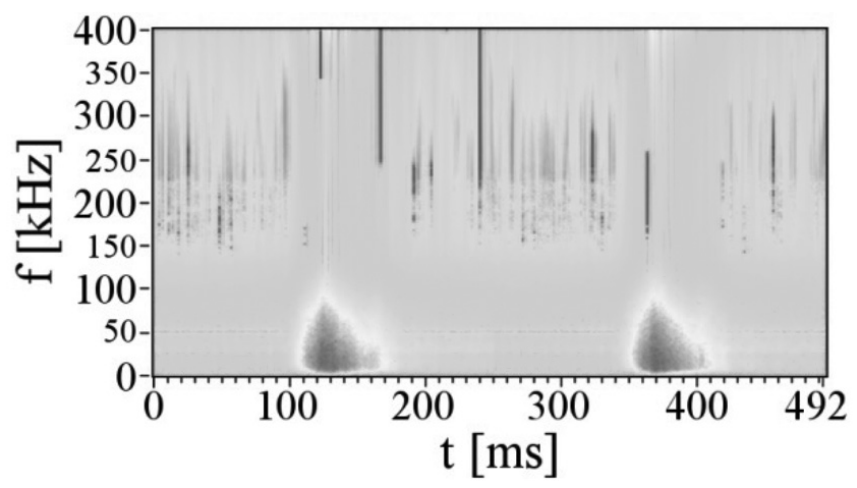

Rys. 9. Spektrogram transformacji Wignera-Ville'a

Fig. 9. Wigner-Ville Transform Spectrogram

\section{Podsumowanie}

Zaprezentowano różne metody analizy ilościowej sygnału napięciowego Barkhausena. Sygnał może być analizowany w dziedzinie czasu, w dziedzinie częstotliwości lub łącznie zarówno w dziedzinie czasu i częstotliwości. Analizy czasowo-czętotliwościowe mogą być zrealizowane różnymi metodami, w których najtrudniejszym zadaniem jest dobranie właściwych tablic dekompozycji sygnału w dziedzinie czasowo-częstotliwościowej oraz wybór funkcji bazowych. Metody te umożliwiają uzyskanie maksymalnej ilości informacji o mierzonym sygnale niestacjonarnym, przy czym ich właściwa interpretacja stanowi duże wyzwanie. 


\section{Literatura}

[1] M. Roskosz, K. Fryczowski: Porównanie szumu Barkhausena i własnego magnetycznego pola rozproszenia w odkształconych plastycznie próbkach ze stali S235 i P265GH, Przegląd Spawalnictwa, Vol 84(13), s. $35-40,2012$.

[2] T. P. Zieliński: Cyfrowe przetwarzanie sygnałów - od teorii do zastosowań, Wydawnictwa Komunikacji i Łączności, Warszawa, 2005.

[3] F. Brailsford: Materiały magnetyczne, Państwowe Wydawnictwo Naukowe, Warszawa, 1964

[4] A. Hubert, R. Schäfer. Magnetic Domains. The analysis of magnetic microstructures, Springer, 2009.

[5] D. M. Clatterbuck, V. J. Garcia, M. J. Johnson, D. C. Jiles: An extended model of the Barkhausen effect based on the ABBM model, Journal of Applied Physics, vol. 87, no. 9, s. 4771-4773, 2000

[6] B. Augustyniak: Zjawiska magnetosprężyste i ich wykorzystanie w nieniszczących badaniach materiałów, Wydawnictwo Politechniki Gdańskiej, 2003.

[7] L. R. Padovese, N. Martin: Analysing MBN signals of different materials by time-frequency methods, Conference Proceedings of Fifth International Conference on Condition Monitoring and $\mathrm{Ma}$ chinery Failure Prevention Technologies, Edinburgh, United Kingdom, s. 1-12, 2008 .

[8] A. Sorsa, S. Santa-Aho et al.: Utilization of frequency-domain information of Barkhausen noise signal in quantitative prediction of material properties, AIP Conf. Proc., vol. 1581 s. 1256-1263, 2014.

[9] T. Liu, H. Kikuchi, Y. Kamada et al.: Comprehensive analysis of Barkhausen noise properties in the cold rolled mild steel, Journal of Magnetism and Magnetic Materials, vol. 310, s. 2006-2008, 2007.

[10] K. Gurruchaga, A. Martinez-De-Guerenu et al.: Magnetic barkhausen noise for characterization of recovery and recrystallization, IEEE Transactions on Magnetics, vol. 46, s. 513-516, 2010.

[11] A. Timofiejczuk: Metody Analizy Sygnałów Niestacjonarnych, Wydawnictwo Politechniki Śląskiej, Gliwice, 2004.

[12] M. Vashista, V. Moorthy: On the shape of the magnetic Barkhausen noise profile for better revelation of the effect of microstructures on the magnetisation process in ferritic steels, Journal of Magnetism and Magnetic Materials, vol. 393, s. 584-592, 2015.

[13] J. Anglada-Rivera, L. R. Padovese, J. Capó-Sánchez: Magnetic Barkhausen Noise and hysteresis loop in commercial carbon steel: Influence of applied tensile stress and grain size, Journal of Magnetism and Magnetic Materials, vol. 231, s. 299-306, 2001.

[14] V. Moorthy, B. A. Shaw, P. Hopkins: Magnetic Barkhausen emission technique for detecting the overstressing during bending fatigue in case-carburised En36 steel, NDT\&E Int., vol. 38, s.159-166, 2005.
[15] M. Lindgren, T. Lepistö: Relation between residual stress and Barkhausen noise in a duplex steel, NDT\&E Int., vol. 36, s. 279-288, 2003

[16] L. Piotrowski, B. Augustyniak, M. Chmielewski et al.: Evaluation of barkhausen noise and magnetoacoustic emission signals properties for plastically deformed armco iron, IEEE Transactions on Magnetics, vol. 46, s. 239-242, 2010

[17] A. Dhar, L. Clapham, D. L. Atherton: Influence of uniaxial plastic deformation on magnetic Barkhausen noise in steel, NDT\&E Int., vol. 34, s. $507-514,2001$

[18] J. Capó-Sánchez, L. Padovese: Magnetic Barkhausen noise measurement by resonant coil method, Journal of Magnetism and Magnetic Materials, vol. 321, s. 57-62, 2009

[19] L. Piotrowski, B. Augustyniak, M. Chmielewski et al: An in-depth study of the Barkhausen emission signal properties of the plastically deformed Fe-2\%Si alloy, IEEE Transactions on Magnetics, vol. 44, s. 3828-3831, 2008

[20] X. Luo, Y. Wang, B. Zhu et al.: Super-resolution spectral analysis and signal reconstruction of magnetic Barkhausen noise, NDT\&E Int., vol. 70, pp. 16-21, 2015

[21] L. B. Magalas: Application of the wavelet transform in mechanical spectroscopy and in Barkhausen noise analysis, Journal of Alloys and Compounds, vol. 310, s. 269-275, 2000.

[22] L. R. Padovese, N. Martin, F. Millioz: Time-frequency and time-scale analysis of Barkhausen noise signals, Proceedings of the Institution of Mechanical Engineers, Part G: Journal of aerospace engineering, vol. 223, s. 577-588, 2009 .

[23] K. Miesowicz, W. J. Staszewski, T. Korbiel: Analysis of Barkhausen Noise Using Wavelet-Based Fractal Signal Processing for Fatigue Crack Detection, International Journal of Fatigue, vol. 83, pp. 109-116, 2015.

[24] J. Błachnio, C. Kownacki: Próba oceny stanu warstwy wierzchniej elementu maszyny z wykorzystaniem analizy falkowej sygnału efektu Barkhausena, Zeszyty Naukowe Politechniki Białostockiej, Budowa i Eksploatacja Maszyn, vol. 10, s. 5-14, 2002.

[25] D. Mężyk: Magnetyczna ocena naprężeń w instalacjach rurociągowych z wykorzystaniem efektu Barkhausena; Przegląd Spawalnictwa, Vol 86(5), 2014

[26] M. Roskosz, K. Fryczowski, S. Griner, A. Katunin: Analiza możliwości oceny procesu pełzania stali X12CrMoWVNbN10-1-1 na podstawie szumu Barkhausena, Przegląd Spawalnictwa, Vol 86(11), 2014 